\title{
Valsts parāda ietekme uz noteiktiem ekonomiskiem rādītājiem ES valstīs
}

\author{
Nadežda Semjonova, Rīgas Tehniskā Universitāte
}

\begin{abstract}
Kopsavilkums. Pēc provizoriskiem novērtējumiem summārais valstu parāds veido vairāk nekā 57 triljonus USD. Vairāki pētījumi rāda, ka valsts parāds var gan stimulēt, gan arī bremzēt valsts ekonomikas attīstību. No Rikardo laikiem valda priekšstats, ka valsts parāds vispār neietekmē ekonomiku. Pētījuma mērkis novērtēt valsts parāda pieauguma mijiedarbību ar noteiktiem ekonomiskiem rādītājiem Eiropas Savienības valstīs. Ir izdarīti šādi secinājumi: aizdevuma likme nav saistīta ar parāda apjomu, ES valstis nemaina nodokḷu politiku atkarībā no parāda apjoma, liels parāda apjoms ilgtermiṇā negatīvi ietekmē IKP pieaugumu.
\end{abstract}

Atslēgas vārdi: valsts parāds, parāda apkalpošanas izdevumi, nodokḷu slogs, IKP pieaugums.

\section{IEVADS}

Ap 96\% pasaules valstu ir saistītas ar starptautiskās ārējās finansēšanas sistēmu. Pēc provizoriskās novērtēšanas, summārais valstu parāds sastāda vairāk nekā 57 triljonus USD [1]. Vairāki pētījumi rāda, ka valsts parāds var gan stimulēt, gan arī bremzēt valsts ekonomikas attīstību (piemērām, [2]). Neoklasiskās pieejas ietvaros no Rikardo laikiem valda priekšstats, ka valsts parāds vispār neietekmē ekonomiku ne īstermina, ne ilgtermina perspektîvā [3].

Klasiskajā darbā Barro [4] analizējis vairāku parametru ietekmi uz ekonomisko pieaugumu, tomēr nav pievērsis uzman̄ibu tieši valsts parādam. Vēlāk tika attīstīti vairāki teorētiskie modeḷi un veikti empīriskie pētījumi, kuros autori vērtēja valsts parāda saistības ar vairākiem ekonomiskiem rādītājiem. Piemēram, Basetto un Kocherlakota [5] teorētiski izskatīja situāciju, ka valsts var palielināt ienākumus, tikai savācot deformējošus nodokḷus (distortionary taxes). Šajā gadījumā ir iespēja pārvaldīt parādu, neietekmējot tirgus ekonomikā sasniegto līdzsvara kapitāla sadalījumu un cenas. Virknē pētījumos autori cenšas noteikt optimālo valsts parāda apjomu, izmantojot modeḷus, kas ņem vērā iedzīvotāju uzkrājumu veidošanu ierobežotas kredītspējas apstākḷıs, iedz̄̄votāju darbspējas izmainas [6,7].

Faraglia et al ievadīja modelī arī novirzes no tirgus idealitātes - transakcijas izmaksas (transaction costs) - un parādīja, ka valdībai izdevīgāk sabalansēt budžetu, nekā lietot ideālā tirgus modeḷa "optimālo" parāda portfeḷa struktūru [8].

Vēl viens svarīgs jautājums, cik lielā mēra parāds ir saistīts ar valsts nodokḷu politiku vai ietekmē to. Piemēram, ASV pastāv tendence palielināt parādu, lai saglabātu esošo nodokḷu līmeni un samazinātu nodokḷu deformējošo ietekmi uz ekonomiku [9].

No otras puses, pēc Raudla un Kattel viedokḷa [10], Baltijas valstu pieredze 2008.-2009. gadā rāda, ka taup̄ōa politika veicina IKP pieaugumu.

Vienā no jaunākajiem darbiem šajā jomā tika analizēta valsts parāda ietekme uz ilgtermiṇa attīstību 12 eirozonas valstīs no 1970. līdz 2010. gadam. Autori norāda, ka valsts parāds, kas pārsniedz $70 \%$ - 80\% no IKP, jau var negatīvi ietekmēt ekonomisko attīstību, bet parāds, kas pārsniedz $90 \%$ $100 \%$ no IKP, noteikti to samazina [11].

Jāatzīmē, ka pēdējos 10 gados ES valstu skaits pieauga. Līdz ar to būtu nepieciešams atkārtot līdzīgo analīzi, ņemot vērā arī jaunuzṇemtās valstis.

Līdzịgā pētījumā par periodu no 1970. līdz 2008. gadam uz 155 valstu bāzes valsts parāda negatīvās ietekmes slieksnis ir $59 \%$ no IKP [12].

Iepriekšminētais pētījums neiekḷauj 2008.-2009. gada recesiju, ka arī sekojošo attīstības periodu. Līdz ar to paliek aktuāls jautājums, cik lielā mērā valdības aizṇēmumu politika veicināja valsts ekonomisko rādīiāju ,atdzīvināšanu”.

Pētījuma mērḳis - novērtēt valsts parāda pieauguma mijiedarbību ar noteiktiem ekonomiskiem rādītājiem Eiropas Savienības valstīs. Pētījuma uzdevumi ir novērtēt korelācijas starp valsts parāda pieaugumu un ekonomiskiem rādītājiem, kā arī novērtēt valsts parāda ietekmi uz nodokḷu politiku ES valstīs.

Interese pētît tieši Eiropas valstis ir saistīta ar to, ka no 2003. gada līdz 2011. gadam valsts parādi tika norakstīti 35 valstīm [13]. Tas notika atbilstoši Starptautiskā Valūtas fonda un Pasaules Bankas kopīgi izstrādātajam dokumentam („Divu soḷu process”), kas nosaka valsts parāda norakstīšanas kārtību valstīm, kam iestājas pirmsdefolta stāvoklis. Rezultātā, ES valstu daḷa ,lielo parādnieku” sarakstā ievērojami pieauga.

\section{DATI UN METODES}

\section{A. Analizējamie rādītāji}

Darbā tika analizēti ekonomiskie rādītāji, kas raksturo valsts pašreizējo ekonomisko situāciju, kā arī parametri, kas ḷauj novērtēt ekonomikas attīstības tendences ilgtermin̄ā:

$Y$ - IKP 2003. un 2011. gadā, mljrd. EUR;

$r$ - IKP pieauguma temps 2003. un 2011. gadā, \% no attiecīgā iepriekšèjā gada;

$D$ - valsts parāda apjoms 2003. un 2011. gadā, \% no IKP;

$p$ - valsts aizṇēmumu vidējā procentu likme 2003. un 2011. gadā;

$T$ - iekasētie nodokḷi (neieskaitot sociālās apdrošināšanas iemaksas) 2003. un 2011. gadā, \% no IKP;

$b$ - nodokḷu slogs 2003. un 2011. gadā. Nodokḷu slogs tika aprēḳināts kā iekasēto nodokḷu daḷa, kas tika izmantota valsts parāda apkalpošanai, izteikts procentos.

$R$ - IKP pieaugums 2011. gadā salīdzinājumā ar IKP 2003. gadā, \%

$\delta$ - valsts parāda pieaugums 2011. gadā salīdzinājumā ar 2003. gadu, procentpunktos;

$\Delta r$ - IKP pieauguma tempa palielinājums 2011. gadā salīdzinājumā ar 2003. gadu, \%;

$\Delta p$ - vidējās procentu likmes pieaugums 2011. gadā salīdzinājumā ar 2003. gadu, \%; 
$\Delta b$ - nodokḷu sloga pieaugums 2011. gadā salīdzinājumā ar 2003. gadu, $\%$.

\section{B. Datu kopa}

Pētījumā tika izmantoti publiski pieejami dati no SVF un „Eirostat” datubāzēm [1, 14]. Tika analizēts periods no 2003. gada līdz 2011. gadam. Perioda izvēli nosaka šādi faktori: pirmkārt, 2004. gadā notika lielas valstu grupas pievienošanās ES, bet jau 2003. gadā kandidātvalstis pildīja ES pievienošanās kritērijus, kas paredz zināmu finansiālu disciplīnu; otrkārt, 2003. gadā sākās parādu norakstīšana SVF un PB programmu ietvaros, kas izmainīja pasaules valstu parādu sadalījumu. Līdz ar to par atskaites punktu tika izvēlēts 2003. gads.

Par pārskata perioda beigu gadu tika izvēlēts 2011. gads, jo šajā gadā jau sākās ekonomisko rādītāju uzlabošanās, un ekonomiskie rādītāji par 2012. gadu vēl nebija pieejami pilnībā.

Darbā tika analizētas 27 ES valstis, ieskaitot 2007. gadā pieņemtās Rumāniju un Bulgāriju. 2013. gadā pieṇemtā Horvātija netika ieskaitīta.

Lai salīdzinātu situāciju ES ar situāciju pasaulē, darbā tiek ieklauti dati par 132 pasaules valstīm, kam SVF datubāzē bija pieejami pilni dati par 2003. - 2011.gadu.

\section{Metodes}

Lai novērtētu Eiropas valstu parādu stāvokli salīizinājumā ar pasauli, tika izmantota aprakstošās statistikas metode. Attiecīgajā gadā tika aprēḳināta valsts parāda mediānas vērtība, 5\%, 25\%, 75\% un $95 \%$ kvartiles. Valstis tika sagrupētas atbilstoši valsts parāda lielumam: tika izveidotas piecas grupas: I. grupā tika iekḷautas valstis, kam parāds ir zemāks par 5\% kvantili; II. grupā bija valstis, kurām parāds bija starp 5\% kvantili un 25\% kvartili (ieskaitot); III. grupā ar parādu starp 25\% un $75 \%$ (ieskaitot) kvartili, IV. grupā ar parāda vērtību starp 75\% kvartili un $95 \%$ kvantili un V. grupāar parādu lielāku par 95\% kvantili.

Parāda ietekme uz ekonomiskajiem rādītājiem tika novērtēta, izmantojot korelācijas metodi. Tika aprēķināts Pīrsona korelācijas koeficients starp katru ekonomisko rādītāju un valsts parāda vērtību 2003. un 2011. gadā., kā arī izveidotas izkliedes diagrammas. Koeficienta statistiskais nozīmīgums tika novērtēts pēc $t-$ kritērija. Darbā pieņemts nozīmīguma limenis $\alpha=0.05$.

\section{REZULTĀTI}

Pētîjuma ietvaros analizētie rādīiāji tika apkopoti pielikumā un korelācijas rādītāji tiek parādīti 3. tabulā.

Eiropas valstu sadalījums pa grupām ir apkopots 1.tabulā. Tabulā atsevišķi izdalītas 27 ES valstis.

1. TABULA

EIROPAS VALSTU SADALĪJUMS PA PARĀDNIEKU GRUPĀM

\begin{tabular}{|c|c|c|c|c|c|}
\hline \multirow[b]{2}{*}{$\begin{array}{l}\text { Eiropas valstu skaits grupā, } \\
\text { kas iekḷauj }\end{array}$} & \multicolumn{3}{|c|}{ 2003. g. } & \multicolumn{2}{|c|}{ 2011. g. } \\
\hline & 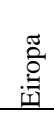 & $\begin{array}{l}\stackrel{*}{=} \\
\overline{0} \\
\tilde{N} \\
\tilde{y}\end{array}$ & $\begin{array}{l}\text { } \\
\delta \\
\text { N } \\
\tilde{S} \\
\text { [II }\end{array}$ & 華 & 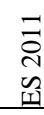 \\
\hline I. 5\% pasaules valstu ar mazāko parādu & 3 & 2 & 1 & 1 & 1 \\
\hline II. $20 \%$ pasaules valstu ar mazo parādu & 10 & 6 & 1 & 5 & 2 \\
\hline III. $50 \%$ pasaules valstu ar vidējo parādu & 25 & 16 & 10 & 21 & 11 \\
\hline IV.20\% pasaules valstu ar lielo parādu & 3 & 3 & 3 & 11 & 10 \\
\hline
\end{tabular}

\begin{tabular}{|l|l|l|l|l|l|}
\hline V.5\% pasaules valstu ar lielāko parādu & & & & 3 & 3 \\
\hline Kopā & 41 & 27 & 15 & 41 & 27 \\
\hline
\end{tabular}

* šajā ailē tika iekḷautas arī valstis, kas pievienojās ES 2004. un 2007. gadā.

Pēc 1. tabulas datiem var redzēt, ka 2003. gadā V. grupā neviena valsts nebija parādniece, bet 2011. gadā valstis ar vislielāko parāda apjomu pasaulē bija jau trīs. To vidū Griekija ar valsts parādu $170,3 \%$ no IKP, Itālija ar $120,8 \%$ no IKP un Portugāle ar 108,3\% no IKP.

I. grupā 2003. gadā bija divas valstis ar vismazāko parādu pasaulē: Igaunija ar 5,6\% un Luksemburga ar 6,1\% no IKP, bet 2011. gadā savu pozīciju saglabāja tikai Igaunija ar valsts parādu $6,2 \%$ no IKP.

Pēc autores domām, l,oti dramatiska situācija izveidojās tieši IV. grupā. Ja 2003. gadā valstu skaits ar lielu parādu sastādīja trīs, tad 2011. gadā tādas valstis jau bija vienpadsmit visā Eiropā, no tām ārpus ES ir tikai viena valsts - Islande ar valsts parādu 100,7\% no IKP. Turklāt dažas ES valstis pēc saviem rādītājiem nemaz nav tik tālu no $\mathrm{V}$. grupas pārstāvjiem. Piemēram: İrija ar valsts parādu $104,1 \%$ no IKP, Beḷgija ar $97,8 \%$ no IKP.

Iepriekšminētais parāda, ka Eiropā un īpaši Eiropas Savienībā salīdzinājumā ar pasauli problēmas ar valsts parādu paliek neatrisinātas.

ES valstu parāda pieaugums pētāmā periodā tiek parādīts 1. att. Ir redzams, kā ES valstu parādi pieaug ne tikai relatīvi uz pasaules fona, bet arī absolūtās vienībās.

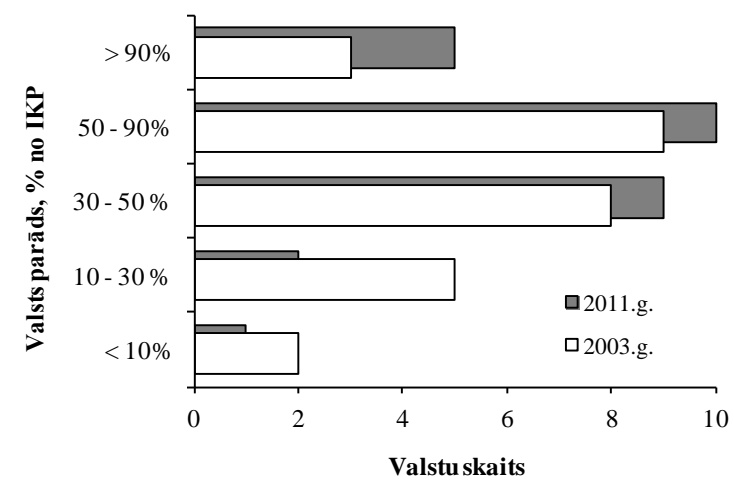

1.att. ES valstu parādu sadalījums 2003. un 2011. gadā.

Ir zināms, ka viens no Māstrihtas kritērijiem ir valsts parāda pret IKP attiecības slieksnis, kas nepārsniedz 60\%. 2003. gadā šo robežu pārsniedza astoņas valstis, bet 2011. gadā - jau 14 valstis. Turklāt lielākā daḷa no tādām valstīm ir ,,vecās” ES dalībnieces.

Ja tādas valstis kā Lielbritānija, Vācija, Francija un Beḷgija veido lielo aizñēmumu politiku, ir aizdomas, ka tām valstīm, kam parāds ir lielāks, aizdevuma procentu likme relatīvi būs mazāka. Turklāt „vecajām” ES valstīm tāda politika bija izveidota sen. 


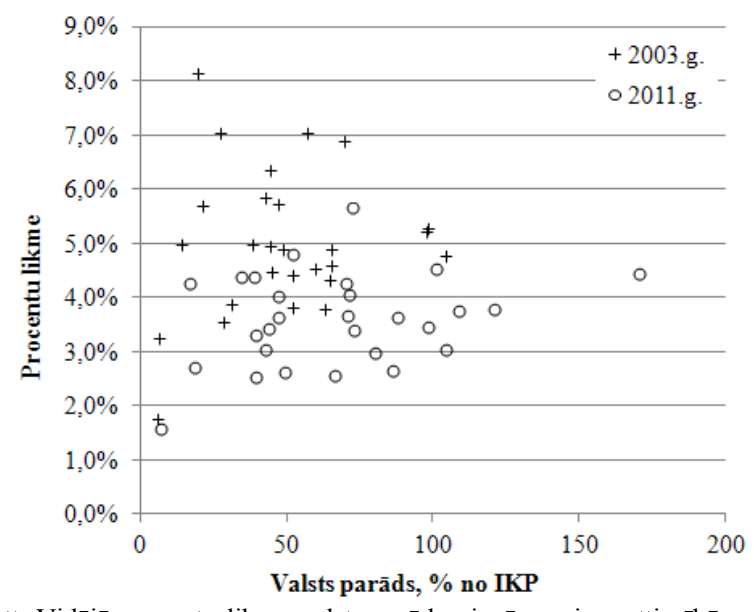

2.att. Vidējā procentu likme valsts parādu aizṇēmumiem attiecībā pret valsts parāda lielumu.

2. att. ir redzams, ka korelācija starp valsts parāda apjomu un aiznēēmumu procentu likmi neeksistē. Tāpēc ES valstu aizņēmumu pieaugumu nevar skaidrot ar lēto kapitāla resursu pieejamību starptautiskajā aizņēmumu tirgū.

Arī pēc 2. att. var redzēt, ka aizdevumu procents 2011. gadā kopumā samazinājās salīdzinājumā ar 2003. gadu, kas ir atspoguliots 2. tab.

2. TABULA

VIDĒJO PROCENTU LIKMES STATISTIKA ES VALSTĪS

\begin{tabular}{|l|l|l|}
\hline & 2003. g. & 2011. g. \\
\hline Maksimālā & $8.16 \%$ & $5.67 \%$ \\
\hline 3/4 kvantile & $5.72 \%$ & $4.29 \%$ \\
\hline Mediānas vērtība & $4.92 \%$ & $3.66 \%$ \\
\hline 1/4 kvantile & $4.38 \%$ & $3.06 \%$ \\
\hline Minimālā & $1.78 \%$ & $1.60 \%$ \\
\hline
\end{tabular}

Neskatoties uz to, ka Griekijas valsts parāds 2011. gadā pārsniedza 170\% no IKP, aizdevumu likme 2011. gadā sastādīja $4.46 \%$, bet 2003. gadā bija 5,23\%. Savukārt maksimālo likmi 5,67\% 2011. gadā izmantoja aizdevumu izsniegšanai Ungārijai, kurai valsts parāds pret IKP 2011. gadā sastādīja 72,3\%. Minimālā procentu likme 1,6\% tika piemērota Igaunijas kreditēšanai.

Ir zināms, ka viens no valsts parādu apkalpošanas finansēšanas veidiem var būt nodokḷu politika. Būtu interesanti novērtēt, kā ES valstu nodokḷu politika reaǵē uz valstu parādu apjomu pieaugumu. Pētijuma rezultāti tiek atspoguḷoti 3.att.

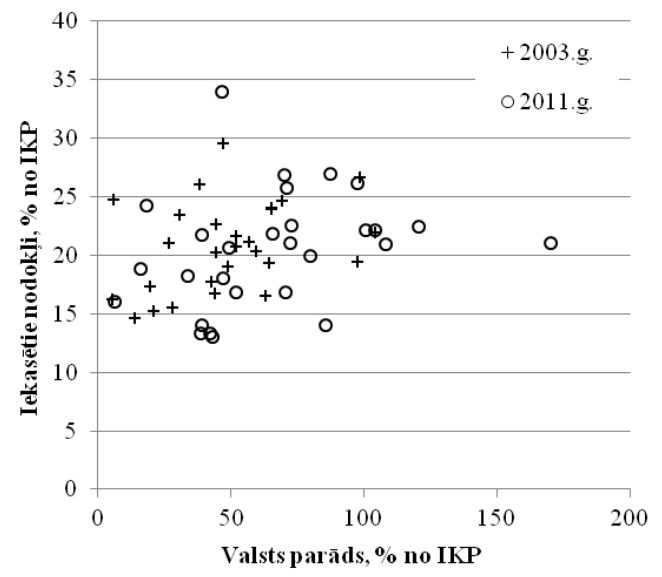

3.att. Iekasētie nodokḷi attiecībā pret valsts parādu.
Rezultāti liecina, ka korelācijas starp valsts parāda lielumu un iekasēto nodokḷu apjomu (bez sociālās apdrošināšanas iemaksām) neeksistē. Dažām valstīm, pieaugot valsts aizņēmumu apjomiem, nodokḷu apjoms paliek iepriekšējā līmenī vai nenozīmīgi pieaug; citām valstīm pat samazinājās.

Piemēram, İrijā neskatoties uz to, ka valsts parāds pētāmā periodā pieauga no $30,8 \%$ līdz $104,1 \%$, iekasēto nodokḷu apjoms samazinājās no $23,5 \%$ līdz 22,2\% pret IKP. Savukārt Dānijā nodokḷu apjoms pieauga attiecīgajā periodā no $29,6 \%$ līdz $34,0 \%$, bet valsts parāda apjoms samazinājās no $47,1 \%$ līdz 46,5\% no IKP.

Tās nozīmē, ka ES valstis nepalielina nodokḷus speciāli valsts parāda apkalpošanai, bet šim nolūkam izmanto refinansēšanu. Tāds secinājums sakrīt ar Berbena un Brosensa [15] secinājumiem, kuri apgalvo, ka valsts ar lieliem parādiem nevar lietot fiskālo politiku biznesa cikla stabilizēšanai.

4.att. tiek parādīta korelācija starp parāda apkalpošanai iztērēto iekasēto nodokḷu dalıu un valsts parādu.

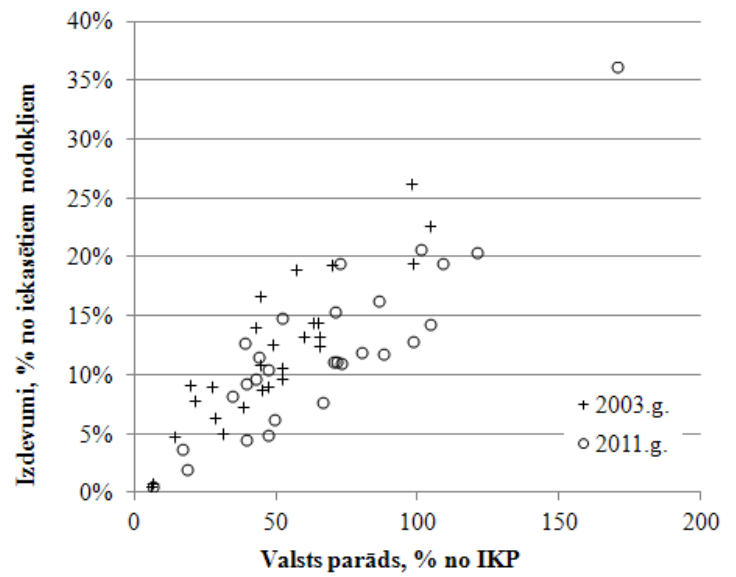

4. att. Parāda apkalpošanai iztēerēta iekasēto nodokḷu daḷa attiecībā pret valsts parādu.

Kaut gan 4. att. rāda prognozējamo rezultātu - jo lielāki ir valsts aizṇēmumi, jo lielāka daḷa no nodokḷu summas tiek izmantota valsts parāda apkalpošanai, tā nerāda nodokḷu sloga piesātināšanos, parāda apjomam pieaugot (korelācijas koeficienti 0.90 un 0.88 attiecīgi 2003. un 2011. gadā, skat. 3. tabulu). Tas nozīmēe, ka parāda palielināšanās samazina valsts rīcībā esošos līdzekḷus. Tam savukārt var būt negatīva ietekme uz IKP. Jāatzīmē, ka nodokḷu slogs kopumā ES valstīs kopš 2003.gada nav mainījies, kaut arī dažās valstīs tas ievērojami pieauga (Griekijai līdz 9,9\%, Īrijai par 9,3\%), bet citām samazinājās (Kiprai līdz 8,2\%, Bulgārijai par 7,2\%).

Kā jau bija minēts, vairāku pētījumu aktuālākais jautājums: vai valsts aizñēmumi veicina valsts ekonomikas attīstību. Šîs problēmas pẹtījuma rezultāti ir parādìti 5.att. 


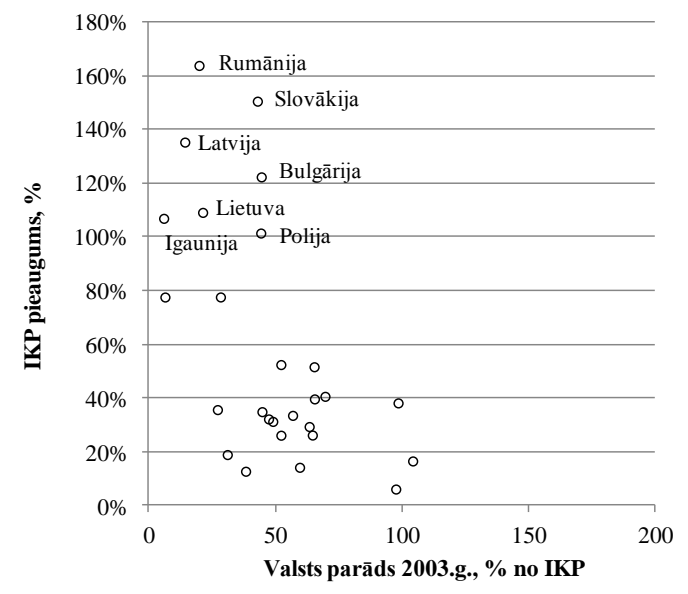

5. att. IKP pieaugums 2011. gadā salīdzinājumā ar 2003. gadu attiecībā pret valsts parādu perioda sākumā.

Pēc 5. att. datiem valstis, kam valsts parāds bija samērā neliels, pētāmajā periodā parādīja lielāko IKP pieauguma tempu. Korelācijas koeficients starp IKP pieaugumu periodā no 2003. gada līidz 2011. gadam un valsts parāda apjomu šî perioda sākumā (2003) bijis $-0.59(P<0.01)$, kas liecina par vidēji izteiktu korelāciju starp šiem rādītājiem. Tomēr, detalizēta 5. att. analīze rāda, ka valstu grupu ar maziem parādiem un lielu pieaugumu veido tikai jaunuzņemtās ES valstis, kam ekonomika joprojām attīstās. Citā valstu grupā, izñemot divas valstis ar lielāko pieauguma tempu (Čehija un Luksemburga), saistība starp parāda apjomu un IKP pieaugumu nav redzama un valsts parāda pieaugums neveicina IKP pieaugumu.

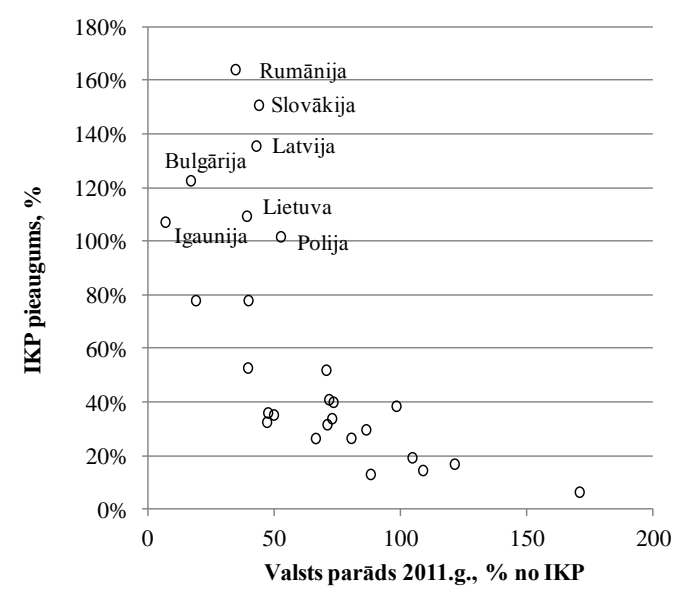

6. att. IKP pieaugums 2011. gadā salīdzinājumā ar 2003. gadu attiecībā pret valsts parādu perioda beigās.

Līdzīga aina ir redzama 6. att., kurā IKP pieaugums ir attēlots atkarībā no parāda 2011. gadā. Šajā gadījumā korelācija starp izaugsmes tempiem un parādu it ievērojami izteiktāka: korelācijas koeficients ir vienāds ar $-0.70(P<0.01)$. Tomēr, spriežot par cēloṇu-seku sakarību, izskatās, ka šajā gadījumā augstākais parāds veidojas tieši tāpēc, ka IKP pieaugums ir zems. Arī šeit jaunuzņemtās valstis var būt izdalītas atsevišķāā grupā. Bet tagad citām valstīm novērojama negatīva korelācija. Turklāt šeit nav redzams parāda „drošības slieksnis”. Negatīva korelācija starp IKP pieaugumu un valsts parāda apjomu 2011. gadā parāda, ka intensīva aizṇemšanās neatviegloja ekonomikas atjaunošanu pēckrīzes periodā. Šis novērojums sakrīt ar tikpat izteiktu negatīvu korelāciju $(-0.70, P<0.01)$ starp IKP gada pieauguma tempu un parāda vērtību 2011. gadā.
Analizējot citu parametru korelācijas ar valsts parādu (3. tabula), interesi izraisa tikai vidēji izteikta korelācija starp parāda vērtību 2003. gadā un parāda pieaugumu pētāmā periodā (korelācijas koeficients - 0.44, $P=0.02$ ). Par to, ka šī korelācija ir negatīva, liecina, ka dažas valstis, kam parāds bijis relatīvi neliels, bet novērojams IKP pieaugums, sāka intensīvi aizņemties.

3. TABULA

KORELĀCIJA STARP VALSTS PARĀDU UN DAŽIEM EKONOMISKIEM RĀDĪTĀJIEM

\begin{tabular}{|l|l|l|}
\hline Rādītājs & Parāds 2003. g. & Parāds 2011. g. \\
\hline IKP, Y & $0.34(P=0.08)$ & $0.34(P=0.08)$ \\
\hline IKP pieauguma temps, $\mathrm{r}$ & $-0.19(P=0.34)$ & $-0.70(P<0.01)$ \\
\hline Aizdevumu procenta likme, $\mathrm{p}$ & $0.13(P=0.51)$ & $0.25(P=0.21)$ \\
\hline Iekasētie nodokḷi, \% no IKP, T & $0.35(P=0.07)$ & $0.26(P=0.18)$ \\
\hline Nodokḷu slogs, b & $0.90(P<0.01)$ & $0.88(P<0.01)$ \\
\hline IKP pieaugums, $R$ & $-0.59(P<0.01)$ & $-0.70(P<0.01)$ \\
\hline Parāda pieaugums, $\delta$ & $-0.44(P=0.02)$ & $0.13(P=0.52)$ \\
\hline Pieauguma tempa izmaiṇas, $\Delta r$ & $-0.24(P=0.22)$ & $-0.40(P=0.04)$ \\
\hline Procentu likmes izmaiṇas, $\Delta p$ & $0.06(P=0.78)$ & $0.13(P=0.50)$ \\
\hline Nodokḷi sloga izmaiṇas, $\Delta b$ & $-0.23(P=0.25)$ & $0.39(P=0.04)$ \\
\hline
\end{tabular}
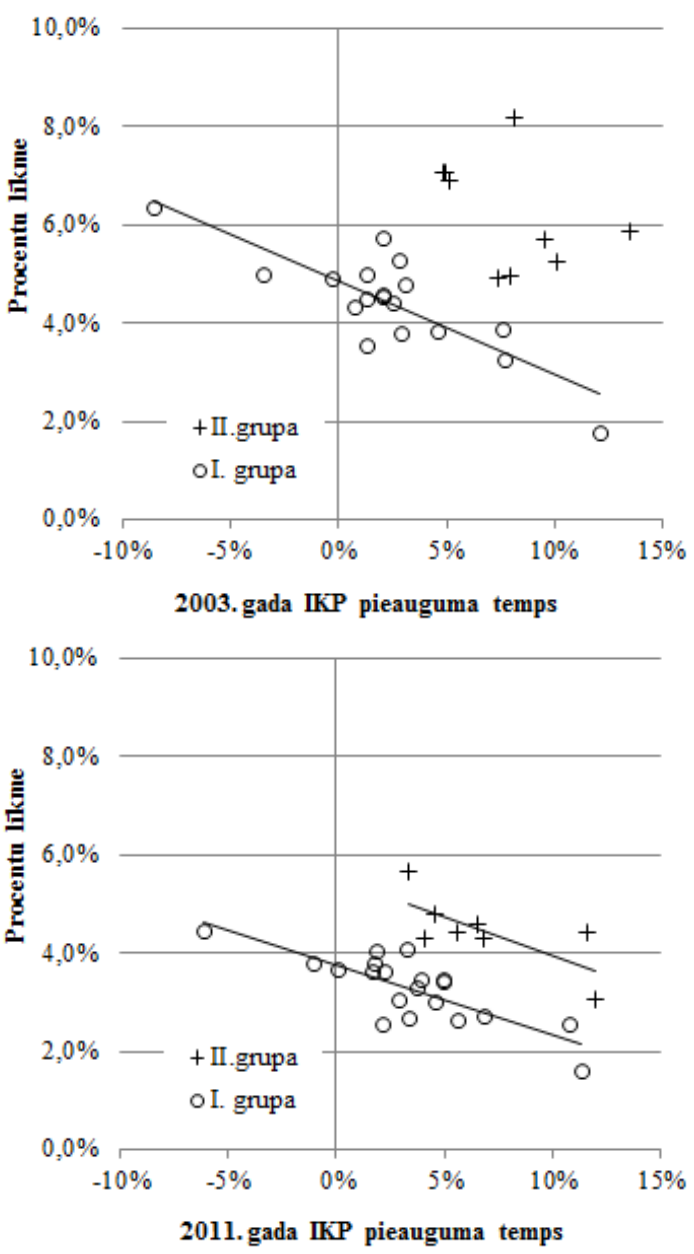

7. att. Valsts aizṇēmumu vidējā procentu likme attiecībā pret IKP pieauguma tempu.

7. att. atspogulota korelācija starp procentu likmi un IKP pieauguma tempu. No 7. att. var redzēt, ka gan 2003. gadā, gan 2011. gadā procentu likme ir mazāka valstīm ar lielāku 
IKP pieauguma tempu. No kopējās tendences izceḷas valstu grupa, kam procentu likme ir lielāka. 2003.gadā starp tām bija Slovēnija, Ungārija, Kipra, Spānija, Bulgārija, Rumānija, Lietuva, Grieķija un Slovākija, bet 2011.gadā - Bulgārija, Ungārija, Latvija, Lietuva, Polija, Malta un Rumānija. Jāatzīmē, ka šajā atsevišķā grupā joprojām lielākiem pieauguma tempiem atbilst mazāki procenti. Valstu izcelšanās cēloṇi šajā grupā nav skaidri. Tos neizdevas saistīt, piemēram, ar kredīta reitingiem: $S \& P$ kredīta reitings Polijai ir augstāks, nekā grupā neiekḷautajām Portugālei vai Kiprai [16].

\section{IV.SECINĀJUMI}

1. Analizējot korelāciju starp ES valstu parāda lielumu un aizdevuma procentu likmi (3.tab.), ir konstatēts, ka procentu likme nav saistīta ar parādu, līdz ar to nevar uzskatīt, ka liela parāda apkalpošana var būt relatīvi lētāka.

2. Konstatēts, ka ES valstis nemaina nodokḷu politiku atkarībā no parāda apjoma. Tas var nozīmēt, ka valstis kredīta dzēšanai izmanto refinansēšanu.

3. Novērota statistiski nozīmīga negatīva korelācija starp ilgtermiņa IKP pieaugumu un valsts parādiem. Tas var nozīmēt, ka, no vienas puses, parāds neveicina ekonomisko attīstību, bet no otras - ka valstis aizṇemas vairāk tieši tad, kad IKP pieauguma tempi ir zemi. Pēc izanalizētajiem datiem nevar secināt par parāda "drošības sliekšṇa" esamību, īpaši valstīm ar attīstītu ekonomiku, t.i., parāda apjoma pieaugums ilgtermin̄ā negatīvi ietekmē IKP pieaugumu.

\section{LITERATŪRA}

[1] Starptautiskā Valūtas fonda datubāze. World Economic Outlook Databases, http://www.imf.org/external/ns/cs.aspx?id=28, accessed 02.09.2013,

[2] .Ludvigson, S The macroeconomic effects of government debt in a stochastic growth model. Journal of Monetary Economics, vol. 38 (1), 1996, pp. 25-45, http://dx.doi.org/10.1016/0304-3932(96)01271-8

[3] Barro, R. J. The Economic effect of Budget Deficits and Government Spending. Journal of Monetary Economics, vol. 20, 1987, pp. 191-193 http://dx.doi.org/10.1016/0304-3932(87)90013-4

[4] Barro, R. J., J-W Lee Sources of economic growth, Carnegie-Rochester Conference Series on Public Policy, Vol. 40, 1994, pp. 1-46, http://dx.doi.org/10.1016/0167-2231(94)90002-7

[5] Bassetto, M., Kocherlakota N. On the irrelevance of government debt when taxes are distortionary. Journal of Monetary Economics vol. 51, 2004, pp. 299-304, http://dx.doi.org/10.1016/j.jmoneco.2002.12.001
[6] Aiyagari, S. R., McGrattan, E. R. The optimum quantity of debt. Journal of Monetary Economics, vol. 42, 1998, pp. 447-469, http://dx.doi.org/10.1016/S0304-3932(98)00031-2

[7] Greiner, A. Public debt in a basic endogenous growth model, Economic Modelling 29 (2012) 1344-1348 http://dx.doi.org/10.1016/j.econmod.2012.03.005

[8] Faraglia, E., Marcet, A. and Scott, A. "In search of a theory of debt management, ” Journal of Monetary Economics, vol. 57, 2010, pp. 821-836,

[9] Martin, F. M. A positive theory of government debt Review of Economic Dynamics, Journal of Monetary Economics, Vol. 12, 2009, pp. 608-631

[10] Raudla, R. and Kattel, R. Fiscal Stress Management During the Financial and Economic Crisis: The Case of the Baltic Countries. International Journal of Public Administration, 36:10, 2013, pp. 732-742.

[11] Checherita-Westphal, C. Ph. Rother The impact of high government debt on economic rowth and its channels: An empirical investigation for the euro area, European Economic Review, vol. 56, 2012, pp. 1392-1405,

[12] Afonso, A., Jalles, J. T. Growth and productivity: The role of government debt, International Review of Economics and Finance, vol. 25, 2013, pp. 384-398,

[13] Debt Relief Under the Heavily Indebted Poor Countries (HIPC) Initiative I IMF Factsheet URL: http://www.imf.org/external/np/exr/facts/hipc.htm, accessed 10.09.2013.

[14] Government deficit and debt. Eurostat databases, http://epp.eurostat.ec.europa.eu/, accessed 02.09.2013,

[15] Berben, R-P., Brosens, T. The impact of government debt on private consumption in OECD countries, Economics Letters, Vol. 94, 2007, pp. 220-225,

[16] Semjonova, N. Structure of the National Debt, Credit Rating and State Financial Security. In: 53th International Riga Technical University Conference ,Scientific Conference on Economics and Enterpreneurship” (SCEE’2012): Proceedings, Latvia, Rīga, 12-16 October, 2012. Riga: RTU, 2012, pp.1-6. ISBN 9789934103551.

\section{Nadežda Semjonova}

No 1994. gada līdz 1997. gadam Rīgas Tehniskās universitātes Inženierekonomikas fakultāte, grāds: Maǵistrs, specialitāte: uznēmējdarbības vadīšana. No 1993. gada līdz 1994. gadam Rīgas Tehniskās universitātes Inženierekonomikas fakultāte, specialitāte: uzṇēmējdarbības vadīšana, inženiera organizatora kvalifikācija

No 2010. gada Rīgas Tehniskā universitāte, Inženierekonomikas fakultāte, amats: Finanšu katedras prakt. docente. No 2007. gada līdz 2010. gadam Rīgas Tehniskā universitāte, Inženierekonomikas fakultāte, amats: Uzṇēmējdarbības un cilvēku resursu vadīšanas katedras prakt. docente. No 2003. gada līdz 2007. gadam Baltijas Krievu institūts, Jelgavas filiāle, ārpus štata lektore. No 1999. gada līdz 2007. gadam Rīgas Tehniskā universitāte, Inženierekonomikas fakultāte, amats: Uznēmējdarbības vadīšanas profesora grupas lektore. No 1999. gada līdz 2001. gadam Valsts arhīvu generāldirekcija, amats: vecākā inspektore.

Adrese: Rīgas Tehniskā universitāte, Kalnciema iela 6 - 312, Rīga, LV-1007, Latvija

Tālrunis un e-pasta adrese: 67089015, nadezda.semjonova@ rtu.lv 
PIELIKUMS

EIROPAS VALSTU EKONOMISKIE RĀDĪTĀJI

\begin{tabular}{|c|c|c|c|c|c|c|c|c|c|c|c|c|c|c|c|c|c|}
\hline \multirow[b]{2}{*}{ Valsts } & \multicolumn{6}{|c|}{2003} & \multicolumn{6}{|c|}{2011} & \multicolumn{5}{|c|}{ Ilgtermiṇa rādītāji } \\
\hline & $Y$ & $r$ & $D$ & $T$ & $p$ & $b$ & $\boldsymbol{Y}$ & $r$ & $D$ & $T$ & $p$ & $b$ & $R$ & $\delta$ & $\Delta r$ & $\Delta p$ & $\Delta b$ \\
\hline Austrija & 225,00 & $2,0 \%$ & $65,3 \%$ & $24,0 \%$ & $4,60 \%$ & $12,5 \%$ & 314,93 & $4,9 \%$ & $72,8 \%$ & $22,6 \%$ & $3,43 \%$ & $11,1 \%$ & $40,0 \%$ & $11,5 \%$ & $2,9 \%$ & $-1,2 \%$ & $-1,4 \%$ \\
\hline Beḷ́ija & 276,16 & $2,8 \%$ & $98,4 \%$ & $26,7 \%$ & $5,29 \%$ & $19,5 \%$ & 382,45 & $3,9 \%$ & $97,8 \%$ & $26,2 \%$ & $3,48 \%$ & $13,0 \%$ & $38,5 \%$ & $-0,6 \%$ & $1,1 \%$ & $-1,8 \%$ & $-6,5 \%$ \\
\hline Bulgārija & 18,37 & $7,9 \%$ & $44,2 \%$ & $20,2 \%$ & $4,97 \%$ & $10,9 \%$ & 40,90 & $6,8 \%$ & $16,3 \%$ & $18,8 \%$ & $4,29 \%$ & $3,7 \%$ & $122,6 \%$ & $-63,1 \%$ & $-1,1 \%$ & $-0,7 \%$ & $-7,2 \%$ \\
\hline Čehija & 84,41 & $1,3 \%$ & $28,1 \%$ & $15,5 \%$ & $3,56 \%$ & $6,5 \%$ & 150,18 & $3,7 \%$ & $39,1 \%$ & $14,0 \%$ & $3,32 \%$ & $9,3 \%$ & $77,9 \%$ & $39,4 \%$ & $2,4 \%$ & $-0,2 \%$ & $2,8 \%$ \\
\hline Dānija & 188,50 & $2,0 \%$ & $47,1 \%$ & $29,6 \%$ & $5,73 \%$ & $9,1 \%$ & 249,80 & $1,7 \%$ & $46,5 \%$ & $34,0 \%$ & $3,66 \%$ & $5,0 \%$ & $32,5 \%$ & $-1,3 \%$ & $-0,4 \%$ & $-2,1 \%$ & $-4,1 \%$ \\
\hline Francija & 1587,90 & $2,9 \%$ & $63,2 \%$ & $16,5 \%$ & $3,80 \%$ & $14,5 \%$ & 2059,36 & $3,3 \%$ & $85,8 \%$ & $14,0 \%$ & $2,68 \%$ & $16,4 \%$ & $29,7 \%$ & $35,8 \%$ & $0,4 \%$ & $-1,1 \%$ & $1,9 \%$ \\
\hline Griekiija & 172,43 & $10,1 \%$ & $97,4 \%$ & $19,4 \%$ & $5,23 \%$ & $26,3 \%$ & 183,52 & $-6,1 \%$ & $170,3 \%$ & $21,0 \%$ & $4,46 \%$ & $36,2 \%$ & $6,4 \%$ & $74,8 \%$ & $-16,2 \%$ & $-0,8 \%$ & $9,9 \%$ \\
\hline Igaunija & 8,72 & $12,1 \%$ & $5,6 \%$ & $16,2 \%$ & $1,78 \%$ & $0,6 \%$ & 18,06 & $11,4 \%$ & $6,2 \%$ & $16,0 \%$ & $1,60 \%$ & $0,6 \%$ & $107,2 \%$ & $11,2 \%$ & $-0,7 \%$ & $-0,2 \%$ & $0,0 \%$ \\
\hline Īrija & 140,64 & $7,6 \%$ & $30,8 \%$ & $23,5 \%$ & $3,90 \%$ & $5,1 \%$ & 167,72 & $2,8 \%$ & $104,1 \%$ & $22,2 \%$ & $3,07 \%$ & $14,4 \%$ & $19,3 \%$ & $238,0 \%$ & $-4,7 \%$ & $-0,8 \%$ & $9,3 \%$ \\
\hline Italija & 1341,85 & $3,1 \%$ & $104,1 \%$ & $22,0 \%$ & $4,80 \%$ & $22,7 \%$ & 1568,39 & $1,7 \%$ & $120,8 \%$ & $22,5 \%$ & $3,81 \%$ & $20,4 \%$ & $16,9 \%$ & $16,0 \%$ & $-1,4 \%$ & $-1,0 \%$ & $-2,3 \%$ \\
\hline Kipra & 11,65 & $5,2 \%$ & $69,4 \%$ & $24,7 \%$ & $6,91 \%$ & $19,4 \%$ & 16,42 & $3,3 \%$ & $71,1 \%$ & $25,8 \%$ & $4,08 \%$ & $11,2 \%$ & $40,9 \%$ & $2,3 \%$ & $-1,9 \%$ & $-2,8 \%$ & $-8,2 \%$ \\
\hline Latvija & 9,94 & $1,3 \%$ & $14,0 \%$ & $14,6 \%$ & $5,01 \%$ & $4,8 \%$ & 23,42 & $12,0 \%$ & $42,3 \%$ & $13,3 \%$ & $3,08 \%$ & $9,8 \%$ & $135,6 \%$ & $202,5 \%$ & $10,8 \%$ & $-1,9 \%$ & $5,0 \%$ \\
\hline Lielbritānija & 1659,74 & $-3,5 \%$ & $38,0 \%$ & $26,1 \%$ & $5,00 \%$ & $7,3 \%$ & 1876,37 & $2,3 \%$ & $87,6 \%$ & $27,0 \%$ & $3,65 \%$ & $11,9 \%$ & $13,1 \%$ & $130,2 \%$ & $5,8 \%$ & $-1,3 \%$ & $4,6 \%$ \\
\hline Lietuva & 16,58 & $9,5 \%$ & $21,0 \%$ & $15,2 \%$ & $5,70 \%$ & $7,9 \%$ & 34,71 & $11,6 \%$ & $38,5 \%$ & $13,3 \%$ & $4,41 \%$ & $12,8 \%$ & $109,4 \%$ & $83,0 \%$ & $2,1 \%$ & $-1,3 \%$ & $4,9 \%$ \\
\hline Luksemburga & 25,82 & $7,7 \%$ & $6,1 \%$ & $24,8 \%$ & $3,27 \%$ & $0,8 \%$ & 45,94 & $6,8 \%$ & $18,3 \%$ & $24,3 \%$ & $2,73 \%$ & $2,1 \%$ & $77,9 \%$ & $199,2 \%$ & $-0,9 \%$ & $-0,5 \%$ & $1,3 \%$ \\
\hline Malta & 4,64 & $-0,3 \%$ & $65,1 \%$ & $24,1 \%$ & $4,91 \%$ & $13,3 \%$ & 7,05 & $4,1 \%$ & $70,0 \%$ & $26,9 \%$ & $4,29 \%$ & $11,2 \%$ & $51,9 \%$ & $7,4 \%$ & $4,4 \%$ & $-0,6 \%$ & $-2,1 \%$ \\
\hline Nīderlande & 476,95 & $2,5 \%$ & $52,0 \%$ & $21,6 \%$ & $4,42 \%$ & $10,6 \%$ & 603,15 & $2,1 \%$ & $65,8 \%$ & $21,9 \%$ & $2,58 \%$ & $7,8 \%$ & $26,5 \%$ & $26,5 \%$ & $-0,4 \%$ & $-1,8 \%$ & $-2,9 \%$ \\
\hline Polija & 191,64 & $-8,6 \%$ & $44,0 \%$ & $16,7 \%$ & $6,36 \%$ & $16,8 \%$ & 386,56 & $4,6 \%$ & $52,0 \%$ & $16,8 \%$ & $4,81 \%$ & $14,9 \%$ & $101,7 \%$ & $18,0 \%$ & $13,2 \%$ & $-1,5 \%$ & $-1,9 \%$ \\
\hline Portugāle & 143,47 & $2,1 \%$ & $59,4 \%$ & $20,3 \%$ & $4,55 \%$ & $13,3 \%$ & 164,30 & $-1,0 \%$ & $108,3 \%$ & $20,9 \%$ & $3,79 \%$ & $19,6 \%$ & $14,5 \%$ & $82,3 \%$ & $-3,1 \%$ & $-0,8 \%$ & $6,3 \%$ \\
\hline Rumānija & 52,58 & $8,1 \%$ & $19,6 \%$ & $17,3 \%$ & $8,16 \%$ & $9,2 \%$ & 138,84 & $5,6 \%$ & $34,0 \%$ & $18,2 \%$ & $4,41 \%$ & $8,2 \%$ & $164,1 \%$ & $73,5 \%$ & $-2,5 \%$ & $-3,8 \%$ & $-1,0 \%$ \\
\hline Slovakija & 29,49 & $13,5 \%$ & $42,7 \%$ & $17,7 \%$ & $5,86 \%$ & $14,1 \%$ & 73,95 & $4,9 \%$ & $43,3 \%$ & $13,0 \%$ & $3,47 \%$ & $11,5 \%$ & $150,8 \%$ & $1,4 \%$ & $-8,6 \%$ & $-2,4 \%$ & $-2,6 \%$ \\
\hline Slovenija & 25,82 & $5,0 \%$ & $26,9 \%$ & $21,0 \%$ & $7,07 \%$ & $9,0 \%$ & 35,11 & $1,9 \%$ & $46,9 \%$ & $18,0 \%$ & $4,05 \%$ & $10,6 \%$ & $36,0 \%$ & $74,4 \%$ & $-3,1 \%$ & $-3,0 \%$ & $1,5 \%$ \\
\hline Somija & 145,53 & $1,3 \%$ & $44,5 \%$ & $22,7 \%$ & $4,49 \%$ & $8,8 \%$ & 196,80 & $5,6 \%$ & $49,2 \%$ & $20,6 \%$ & $2,64 \%$ & $6,3 \%$ & $35,2 \%$ & $10,6 \%$ & $4,3 \%$ & $-1,9 \%$ & $-2,5 \%$ \\
\hline Spānija & 783,08 & $7,4 \%$ & $48,8 \%$ & $19,0 \%$ & $4,92 \%$ & $12,6 \%$ & 1030,52 & $0,1 \%$ & $70,4 \%$ & $16,8 \%$ & $3,69 \%$ & $15,5 \%$ & $31,6 \%$ & $44,3 \%$ & $-7,3 \%$ & $-1,2 \%$ & $2,8 \%$ \\
\hline Ungārija & 73,88 & $4,9 \%$ & $56,6 \%$ & $21,1 \%$ & $7,06 \%$ & $19,0 \%$ & 98,89 & $3,3 \%$ & $72,3 \%$ & $21,0 \%$ & $5,67 \%$ & $19,5 \%$ & $33,8 \%$ & $27,6 \%$ & $-1,5 \%$ & $-1,4 \%$ & $0,6 \%$ \\
\hline Vācija & 2147,50 & $0,7 \%$ & $64,4 \%$ & $19,3 \%$ & $4,35 \%$ & $14,5 \%$ & 2717,12 & $4,6 \%$ & $79,9 \%$ & $19,9 \%$ & $3,00 \%$ & $12,1 \%$ & $26,5 \%$ & $24,0 \%$ & $3,9 \%$ & $-1,3 \%$ & $-2,4 \%$ \\
\hline Zviedrija & 278,91 & $4,6 \%$ & $52,0 \%$ & $20,7 \%$ & $3,85 \%$ & $9,7 \%$ & 426,05 & $10,8 \%$ & $38,9 \%$ & $21,8 \%$ & $2,57 \%$ & $4,6 \%$ & $52,8 \%$ & $-25,1 \%$ & $6,2 \%$ & $-1,3 \%$ & $-5,1 \%$ \\
\hline
\end{tabular}

\section{Nadezhda Semjonova. Effect of the Public Debt on Some Economic Indexes in the EU Member States}

At the present moment, around $96 \%$ of the world countries intensively use foreign financing, and estimations show that the total value of the world public debt exceeds $57 \mathrm{trln}$. USD. The impact of the government debt on the state economy is still controversial: there is evidence that it may either stimulate or depress economic development. Neoclassic approach based on Ricardo theory claims that the debt has no influence on the growth at all. Recent researches have demonstrated the existence of the "growth threshold": public debt less than $60 \%$ of GDP stimulates growth, while the debt that exceeds the threshold has a negative impact. These researches have either concentrated on "old EU countries", or do not account for the recession of 2008 - 2010 . The present paper analyses the influence of public debt on the number of economic parameters in the EU countries over the period of $2003-2011$. In the recent years, the public debt of the EU countries has been growing, as compared with the rest of the world. Recession forced some countries to borrow intensively, but the question persists to what extent the borrowing helped to promote economic growth. The paper is based on the analysis of public available data from SMF and Eurostat databases, concerning $27 \mathrm{EU}$ states, being members of the EU in 2011. The correlations between public debt and average debt interest rate, taxation rate and long-term growth (evaluated as GDP in 2011 in comparison to 2003) were investigated. The findings demonstrate that there is no correlation between the taxation rate and the debt. This means that EU states do not tend to repay debts, but rather try to re-finance them. There is no correlation between debt itself and debt interest rate; so intensive borrowing in the EU may not be explained by the availability of "cheap money". Besides, there is a significant negative correlation between longterm growth and debt both before recession (2003) and after recession (2011). Countries that had low debt in 2003 demonstrated higher GDP growth during $2003-$ 2011. The negative correlation between growth in $2003-2011$ and the value of debt in 2011 suggests that intensive borrowing does not help to recover after the crisis. In any case, there was no clear threshold observed for the negative impact of the public debt: in the framework of existing data scattering, the highest level of debt was always associated with lower growth indicators.

\section{Надежда Семёнова. Влияние государственного долга на некоторые экономические показатели стран ЕС}

В настоящее время до $96 \%$ стран интенсивно используют заимствования на внешних финансовых рынках: совокупный долг государств мира превышает 57 трлн. долларов США. Оценки влияния государственного долга на развитие экономики страны противоречивы: существуют как свидетельства того, что государственный долг стимулирует рост экономики, так и противоположные. Неоклассический подход, восходящий еще к идеям Рикардо, вообще утверждает отсутствие такового. Недавние исследования показали существование «порога роста»: долг, величина которого составляет менее $60 \%$ от ВВП, благотоворно влияет на развитие, в то время как больший долг тормозит рост. Однако, эти исследования или рассматривали только «старые» государства ЕС, или же не учитывали период рецессии 2008 - 2010 гг. В данной работе рассмотрено влияние государственного долга на некоторые экономические показатели стран ЕС в период с 2003 по 2011 г. В последние годы долг государств Евросоюза значительно вырос на фоне остальных государств мира. Рецессия вынудила многие государства интенсивно занимать, однако вопрос о том, насколько эти заимствования способствовали восстановлению экономики, остается открытым. В статье использованы данные МВФ и Евростата о 27 государствах, являющихся членами Евросоюза в 2011 г: исследованы корреляции между величиной долга и средней процентной ставкой госдолга, ставкой налогообложения и долговременным ростом ВВП за период 2003 - 2011 гг. Результаты показали отсутствие корреляции между ставкой налогообложения и величиной долга. Это значит, что государства не стремятся выплатить долги, а ограничиваются рефинансированием. Также отсутствует корреляция между долгом и процентной ставкой по долгу, поэтому увеличение заимствований стран ЕС нельзя объяснить наличием «дешевых денег». В то же время, существует значимая отрицательная корреляция между ростом ВВП в 2003 - 2011 и величиной долга как в 2003 , так и в 2011 г. Страны, имеющие небольшой долг в 2003, показали больший рост за период с 2003 по 2011 г. Наличие отрицательной корреляции между ростом в 2003 - 2011 г. и величиной долга в 2011 показывает, что интенсивное заимствование не облегчает восстановление после кризиса. В любом случае, на основании проанализированных данных нельзя сделать вывод о наличии порога негативного влияния государственного долга: в рамках наблюдаемого разброса данных более высокий уровень долга всегда связан с меньшими значениями показателя роста. 